\title{
Opportunities and constraints for implementing integrated land-sea management on islands
}

\author{
STACY D. JUPITER ${ }^{* 1}$, AMELIA WENGER ${ }^{2,3}$, CARISSA J. KLEIN ${ }^{3}$, \\ SIMON ALBERT ${ }^{4}$, SANGEETA MANGUBHAI ${ }^{5}$, JOANNA NELSON ${ }^{6,7}$, \\ LIDA TENEVA ${ }^{8}$, VIVITSKAIA J. TULLOCH ${ }^{9}$, ALAN T. WHITE ${ }^{10}$ AND \\ JAMES E.M. WATSON T $^{3,11}$ \\ ${ }^{1}$ Wildlife Conservation Society, Melanesia Program, 11 Ma'afu St, Suva, Fiji, ${ }^{2}$ Australian Research Council \\ Centre of Excellence for Coral Reef Studies, James Cook University, Tomnsville, Queensland 4811, Australia, \\ ${ }^{3}$ School of Earth and Environmental Science, University of Queensland, St. Lucia, Queensland 4072, Australia, \\ ${ }^{4}$ School of Civil Engineering, University of Queensland, St Lucia, Queensland 4072, Australia, ${ }^{5}$ Wildife \\ Conservation Society, Fiji Country Program, 11 Ma'afu St, Suva, Fiji, ${ }^{6}$ The Nature Conservancy, Arlington, VA \\ 22203, USA, ${ }^{7}$ The Natural Capital Project, Stanford University, Stanford, CA 94305, USA, ${ }^{8}$ Conservation \\ International, 7192 Kalaniana' ole Hwy, Honolulu, HI 96825, USA, ${ }^{9}$ Australian Research Council Centre of \\ Excellence for Environmental Decisions, School of Biological Sciences, University of Queensland, St Lucia, \\ Queensland 4072, Australia, ${ }^{10}$ Tetra Tech, Sustainable Ecosystems Advanced (SEA) Project, Fakarta, Indonesia \\ and ${ }^{11}$ Wildlife Conservation Society, Global Conservation Program, 2300 Southern Boulevard, Bronx, NY \\ 10460, USA
}

Date submitted: 11 June 2016; Date accepted: 28 January 2017; First published online 13 March 2017

\section{SUMMARY}

Despite a growing body of literature on integrated land-sea management (ILSM), very little critical assessment has been conducted in order to evaluate ILSM in practice on island systems. Here we develop indicators for assessing 10 integrated island management principles and evaluate the performance of planning and implementation in four island ILSM projects from the tropical Pacific across different governance structures. We find that where customary governance is still strongly respected and enabled through national legislation, ILSM in practice can be very effective at restricting access and use according to fluctuations in resource availability. However, decision-making under customary governance systems may be vulnerable to mismanagement. Governmentled ILSM processes have the potential to design management actions that address the spatial scale of ecosystem processes and threats within the context of national policy and legislation, but may not fully capture broad stakeholder interests, and implementation may be poorly coordinated across highly dispersed island archipelagos. Private sector partnerships offer unique opportunities for resourcing island ILSM, although these are highly likely to be geared towards private sector interests that may change in the future and no longer align with community and/or national objectives. We identify consistent challenges that arise during

*Correspondence: Dr Stacy D. Jupiter email: sjupiter@wcs.org Supplementary material can be found online at https://doi.org/ $10.1017 /$ S0376892917000091 island ILSM planning and implementation and offer recommendations for improvement.

Keymords: integrated coastal management, integrated island management, community-based management, management implementation, tropical Pacific

\section{INTRODUCTION}

Isolation of island systems from continental landmasses has promoted unique biological and cultural attributes, particularly on small, remote islands (MacArthur \& Wilson 1967). There is also especially tight connectivity between land and sea on high islands given the generally smaller sizes of their watersheds compared with those on continents (Ruddle $e t$ al. 1992; Jenkins et al. 2010). However, because these ecosystem connections operate across small geographies, the health and wellbeing of island peoples are highly vulnerable to largescale disturbances (e.g. from tropical cyclones or flooding) that disrupt ecosystem processes and functions operating across multiple realms (Griffith \& Ashe 1993; Aston 1999; Jenkins \& Jupiter 2015). For instance, in-stream water quality and biodiversity can be degraded following periods of high rainfall and flooding: in high island watersheds with high rates of deforestation on erosion-prone soils, researchers have documented reduced abundance and diversity of freshwater resources and increased in-stream bacteria and incidence of waterborne bacterial disease (Jenkins \& Jupiter 2011; Ragosta et al. 2011; Jenkins et al. 2016). Given the small size of many islands and often complex tenure or private property arrangements, affected island people may have limited opportunities to replace loss and damage to the natural resources upon which they depend for ecosystem service provisioning, thus heightening the need for proactive, integrated management across linked land and sea realms. 
Table 1 Definitions of environmental management approaches applied in order to safeguard linked land and sea resources, with special reference to implementation in island systems (adapted from Jupiter et al. 2014a).

\begin{tabular}{|c|c|c|}
\hline Approach & Definition and relevance to islands & Supporting reference \\
\hline $\begin{array}{l}\text { Community-based } \\
\text { adaptive management }\end{array}$ & $\begin{array}{l}\text { Integration of design, management and monitoring in order to learn and to } \\
\text { improve responses to management efforts carried out by, or with a major } \\
\text { role played by, local communities. In island systems, communities often } \\
\text { have the ability to influence management over linked terrestrial and marine } \\
\text { ecosystems at the scale in which ecosystem processes and threats are } \\
\text { occurring. }\end{array}$ & Govan et al. (2008) \\
\hline Customary management & $\begin{array}{l}\text { Management of natural resources and systems as part of customary practice } \\
\text { and institutions. For example, many Pacific Island peoples retain customary } \\
\text { tenure over land and sea ecosystems and resources and can self-define rules } \\
\text { for their access and use. }\end{array}$ & Ruddle et al. (1992) \\
\hline $\begin{array}{l}\text { Ecosystem-based } \\
\text { management }\end{array}$ & $\begin{array}{l}\text { Management of the cumulative impact of human activities in order to maintain } \\
\text { ecosystems in a healthy, productive and resilient condition for the delivery } \\
\text { of ecosystem services and the protection of biodiversity. Application of } \\
\text { integrated land-sea management on island systems is a specific form of } \\
\text { ecosystem-based management that targets the maintenance of ecosystem } \\
\text { services and biodiversity that rely on connections between land and sea. }\end{array}$ & Clarke \& Jupiter (2010a) \\
\hline $\begin{array}{l}\text { Integrated coastal (zone) } \\
\text { management }\end{array}$ & $\begin{array}{l}\text { A conscious management process that acknowledges the inter-relationships } \\
\text { among the multiple objectives for the use of coastal areas and the } \\
\text { environments that are affected by those uses. Islands are bound by } \\
\text { coastlines and thus integrated coastal (zone) management should form an } \\
\text { integral part of any natural resource management scheme. }\end{array}$ & Cicin-Sain \& Knecht (1998) \\
\hline $\begin{array}{l}\text { Integrated island } \\
\text { management }\end{array}$ & $\begin{array}{l}\text { Sustainable and adaptive management of island natural resources through } \\
\text { coordinated networks of institutions and communities that bridge habitats } \\
\text { and stakeholders at the scale of social-ecological processes and threats, with } \\
\text { the common goals of maintaining ecosystem services and securing human } \\
\text { wellbeing. }\end{array}$ & Jupiter et al. (2014a) \\
\hline $\begin{array}{l}\text { Integrated land-sea } \\
\text { management }\end{array}$ & $\begin{array}{l}\text { Management that specifically targets cross-system threats and processes } \\
\text { between linked terrestrial, freshwater and marine ecosystems in order to } \\
\text { maintain or restore biodiversity, ecosystem services and human wellbeing. } \\
\text { Because of the geographic proximity between water catchments and coastal } \\
\text { marine areas in island systems, cross-realm processes and ecosystem } \\
\text { functions are more easily disrupted by large-scale disturbances and thus } \\
\text { require heightened consideration for integrated management. }\end{array}$ & Álvarez-Romero et al. (2011) \\
\hline
\end{tabular}

A number of environmental management approaches have been applied in order to safeguard island ecosystem functionality and maintain or increase the adaptive capacity of island social-ecological systems to respond to environmental change, which include community-based adaptive management, customary management, ecosystembased management, integrated coastal management and integrated island management (IIM) (Table 1) (Jupiter et al. 2014a). Integrated land-sea management (ILSM), which specifically targets cross-system threats and processes (Table 1), can be applied on islands within the context of any of the above environmental management approaches in order to maintain or restore sensitive biodiversity, ecosystem services and human wellbeing. Important cross-system processes to maintain on islands include nutrient subsidies, which can influence the productivity and diversity of linked ecosystems (e.g. Polis \& Hurd 1996; Anderson \& Polis 1999), and species' movements across their life history stages (Polis et al. 1997; Hazlitt et al. 2010; Jenkins et al. 2010). Cross-system threats requiring management stem from both land-based activities that affect marine realms (Stoms et al. 2005) and maritime activities that affect other realms (Gresh et al. 2000).

Yet despite a growing number of projects on islands funded under ILSM initiatives with differing environmental management approaches and governance structures, very few in practice are able to effectively manage these crosssystem threats and processes in order to achieve biodiversity protection and positive livelihood outcomes (Álvarez-Romero et al. 2011; Adams et al. 2014; Jupiter et al. 2014a). Recent reviews (e.g. Álvarez-Romero et al. 2011; Álvarez-Romero et al. 2015; Reuter et al. 2016) highlight several hurdles to achieving effective ILSM outcomes in both continental and island systems. Barriers to effective ILSM planning and implementation include: (1) lack of mechanisms to coordinate institutions with different mandates and area jurisdictions across levels of government and between public and private sectors (Cicin-Sain \& Belfiore 2005; Lane 2008); (2) conflict arising due to poor involvement of the full range of stakeholders with interests across the land and sea divide (Reuter et al. 2016); (3) an inability to address 
potentially conflicting objectives and mandates across agencies (e.g. conservation through sustainable use versus economic gain from commercial extraction) (Álvarez-Romero et al. 2011); (4) a lack of adequate data on ecosystem responses to management measures in order to appropriately prioritize actions, particularly with regards to multi-objective project goals (Álvarez-Romero et al. 2015); (5) uncertainty about the effects of management actions across connected realms (Adams et al. 2014); and (6) the labour, time and complexity of analyses required to develop and/or adapt models and decision support systems that deal with the above issues (ÁlvarezRomero et al. 2011). ILSM project implementation may be further hampered by the inability of responsible agencies and institutions to simultaneously schedule management actions in linked terrestrial and marine realms in order to comprehensively address threats at appropriate spatial and temporal scales (Álvarez-Romero et al. 2011).

Despite a large body of potential socioeconomic, governance and environmental indicators (e.g. Ehler 2003; Pollnac \& Pomeroy 2005), little monitoring and evaluation has been conducted in order to assess ILSM planning and implementation (Christie 2005), although there are a few island examples that have been showcased as successes (Jupiter et al. 2014a). Here we provide novel indicators for island ILSM based on 10 IIM principles (Jupiter et al. 2014a) built on Ostrom's (1990) framework for the sustainable governance of common-pool resources that can be used to evaluate the potential effectiveness of island ILSM planning and implementation for managing cross-system processes and mitigating cross-system threats. We use our indicators in order to evaluate four island ILSM projects across community-, government- and private sector-led approaches. We showcase how each project embodies some aspects of best practice for ILSM and highlight the challenges faced. We then provide some recommendations for how the challenges may be addressed in order to improve island ILSM outcomes.

\section{METHODS}

\section{Development of ILSM indicators}

An expert working group convened in April 2015 to propose a list of monitoring and evaluation indicators within the context of 10 principles designed to guide best practice for IIM (Jupiter et al. 2014a). The principles are based on commonpool resources theory (e.g. Ostrom 1990; Cox et al. 2010) and consultations with regional practitioners (Jupiter et al. 2014a). The IIM principles, which can be grouped into planning and implementation categories, provide a clear framework under which island ILSM projects can be evaluated. Indicators were refined during a second workshop in January 2016, yielding a list of 32 such indicators (Table $2 \&$ Table S1 (available online)). Of these, $22(68.8 \%)$ specifically relate to ILSM, while the remaining indicators characterize aspects of best practice management that are relevant to any IIM project (Table 2). The principles and indicators are not necessarily unique to island settings, but given smaller geographies, there are faster and tighter feedbacks between social and ecological systems across island terrestrial and marine realms, heightening the need for integrated management. Community and government managers, particularly in remote island settings, may additionally benefit from more efficient resource allocation through the integration and coordination of activities across sectors and realms in order to achieve mutual aims of maintaining ecosystem services and securing human health and wellbeing (Lane 2006; Jupiter et al. 2014a).

\section{Case selection and scoring}

We selected four island ILSM projects from locations in the tropical western Pacific where there was adequate information from the literature or place-based expert knowledge to assess the characteristics of ILSM planning and implementation against the indicators (Fig. 1). Although we recognize the limitations of generalizing from our small sample size, we found that, similar to Jupiter et al. (2014a), very few island ILSM projects exist with adequate documentation on planning and implementation to enable critical evaluation. The selected projects cover a range of geographic scales, governance and management systems, including: (1) customary management of a single community of $c .150$ people, with little external input and resources (Zaira Village, Solomon Islands); (2) community-based management at the district level, covering 10 villages and $c .1000$ people, with financial and technical support from non-governmental organization (NGO) partners (Kubulau District, Fiji); (3) provincial-level government decision-making and prioritization, operating within the context of indigenous tenure systems across entire island systems with $c .450,000$ residents (New Britain, Papua New Guinea (PNG)); and (4) top-down management from a private sector company that owns $98 \%$ of an island with $c$. 3100 local residents (Lāna'i, Hawaíi) (Table 3).

In order to evaluate the projects, designated co-authors who were most familiar with each region entered supporting information into an Excel database from the literature and their own experiences regarding project planning and implementation as they related to the measurement of each indicator. In order to maintain some objectivity, only co-authors who were uninvolved in project planning and implementation scored each project on performance against each indicator using uniform scoring criteria (Table S2). Results were averaged across all scorers and the performance of each ILSM project against the indicators is described. Evaluation of these four projects is meant to highlight factors that contribute to successful planning and implementation while raising challenges that may ultimately impact ILSM outcomes and thus provide learning opportunities in order to improve practice at other sites. We hypothesize that projects that score highly across most indicators will be most successful at delivering on management objectives, which largely focus on protecting biodiversity, maintaining ecosystem functions and providing ecosystem services for human health, cultural 
Table 2 Indicators designed to evaluate island integrated land-sea management projects associated with the 10 integrated island management principles from Jupiter $\mathrm{et} \mathrm{al}$. (2014a). $\mathrm{P}=$ principle related to planning; $\mathrm{I}=$ principle related to implementation. ${ }^{*}$ Indicator specific to integrated land-sea management projects.

\begin{tabular}{l}
\hline \hline Principle \\
1. Adopt a long-term, integrated \\
approach to ecosystem \\
management $(\mathrm{P})$ \\
\\
2. Use clearly defined boundaries \\
for ecological and governance \\
systems (P)
\end{tabular}

3. Maintain and restore connectivity between complex social and ecological systems $(\mathrm{P})$

\section{Incorporate stakeholders} through participatory governance with collective choice arrangements that consider gender and social equity outcomes (P)

5. Ensure that management rules reflect/incorporate local values and conditions $(\mathrm{P})$

6. Ensure recognition of rights to organize and develop management rules (I)

7. Develop appropriate sanctions for users who violate rules (I)

8. Identify appropriate, efficient and cost-effective conflict resolution mechanisms (I)

9. Implement adaptive management where regular monitoring, evaluation and review in the face of uncertainty lead to evidence-based decision-making (I)

10. Nest management layers across sectors, social systems and habitats $(\mathrm{P}, \mathrm{I})$

\section{Indicator}

a. Explicit timeframe of implementation stated (including overall timescale and review frequency)

b. Proportion of linked ecosystems incorporated in plan*

c. Presence of coordination body or mechanism to integrate sectors (e.g. public versus private; land versus sea mandates)*

d. Accounting for the cumulative impact of multiple threats to the coastal zone*

e. Accounting for lag time for impacts to be realized and benefits from management to accrue across realms*

f. Objectives integrate ecological, social, economic and cultural issues and feedbacks that account for the connectivity between land and sea realms*

a. Degree to which the spatial boundaries of the management zone match the boundaries of watersheds and linked coastal areas*

b. Management boundaries represent the scale of ecological processes and threats for priority features that are relevant to integrated land-sea management*

c. Resource users are aware of management boundaries

d. Decision-makers and decision-making processes are clearly identified

a. Appropriate strategies proposed and management actions identified in order to minimize land-based threats to downstream systems relative to the number of issues*

b. Appropriate strategies are proposed and management actions are identified in order to restore connectivity processes relative to the number of issues*

c. Strength of social networks that connect people using land and sea resources*

a. Proportion of population who access and use land and sea resources in the management area are able to participate in management planning and implementation*

b. Proportion of different sectors and stakeholder groups across land and sea realms are participating relative to presence in area*

c. Opportunities for input from marginalized sectors of communities in affected areas

d. Consistency of mandate through changes in political leadership

a. Management objectives reflect local concerns and issues related to cross-system threats and processes*

b. Local perception that the benefits of management outweigh costs

c. Equity in distribution of management costs and benefits across land and sea resource users*

a. Level (formal or informal) of recognition of management authority

b. Clearly defined and demarcated ownership of both land and sea and use rights of land and sea resources*

a. Frequency and effectiveness of monitoring, control and surveillance integrated across land and sea realms*

b. Proportion of offenses that are adequately punished across both land and sea*

a. Existence of forum or means to settle disputes

b. Perception that conflict resolution is handled fairly and in a culturally appropriate way

a. Monitoring information relevant to the spatial scale of the impacts of human activities on linked ecosystems and responses of linked ecosystems to management interventions are communicated to decision-makers*

b. Decision-makers use relevant information to adapt management measures*

c. Adaptions to rules consider present and future uncertainty regarding cross-realm threats and processes*

a. Management actions/monitoring is carried out by individuals across land and sea realms who report to a coordinating body*

b. Frequency and consistency of communication between lower to higher scales of nested systems (upward and downward communication)

c. Consistency in goals and motivations between nested levels in achieving integrated land-sea management outcomes* 


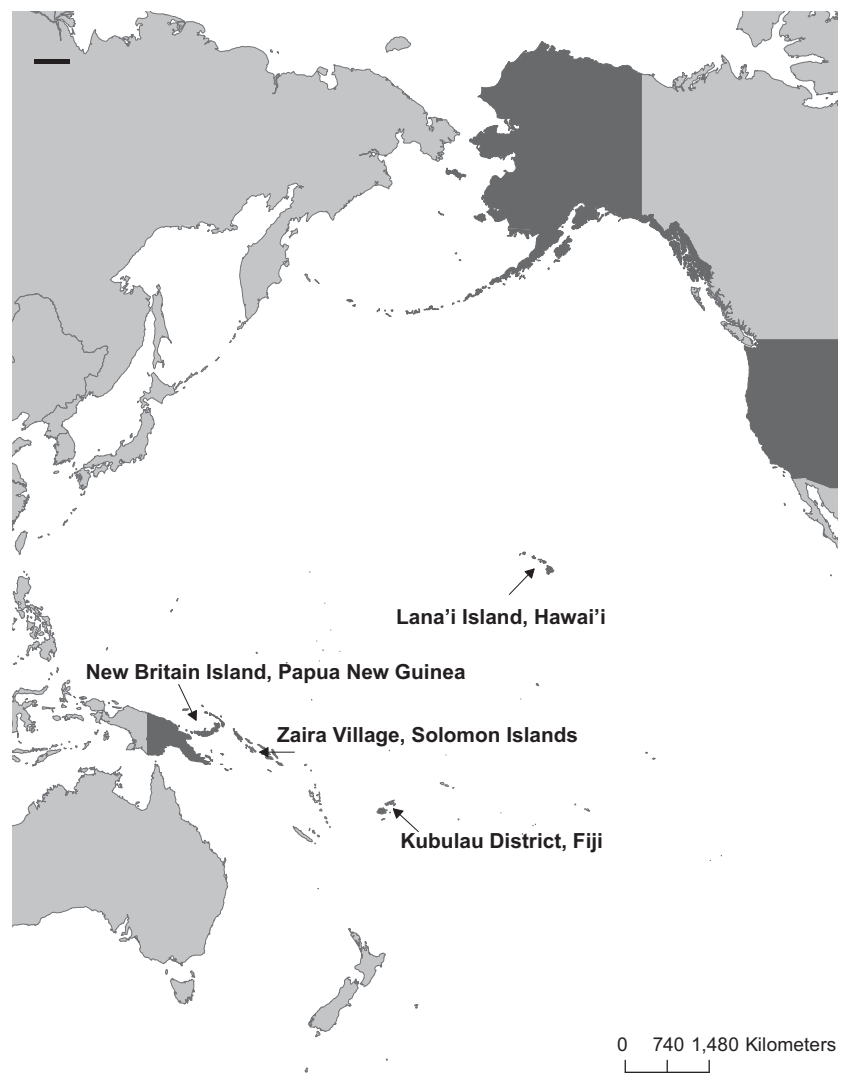

Figure 1 Locations of four island integrated land-sea management projects in the tropical Pacific.

practice and wellbeing (Table 3). For projects where periodic monitoring data have been collected, additional indicators could also be used to measure ILSM outcomes for biodiversity and livelihoods (e.g. changes in coral health and fish catch as a response to watershed management), although this is beyond the scope of this assessment because two of the projects (New Britain and Lāna'i) are still in their planning phases.

\section{RESULTS}

\section{Zaira Village, Solomon Islands}

\section{Positive attributes}

The Zaira project scored consistently highly on indicators related to: adopting a long-term integrated approach to management; using clearly defined management boundaries at the appropriate scale; accounting for connectivity between ecological realms and social networks; ensuring management systems reflect local values; monitoring and punishing offenders; and resolving conflicts (indicators associated with principles $1-3,5,7$ and 8 ; Table 4). Through a commitment to longstanding cultural values, the three tribal groups that form Zaira have successfully managed their linked land and sea resources for millennia under a customary management system, which allows certain resources to be restricted at certain times and considers connectivity and feedback between the cultural interactions of people with land and sea systems
(Table 4, indicators 3a-c) (Hviding 1996). The customary practices are generally regarded as fair and equitable within the local social contexts (Table 4, indicators 5a-c). Zaira community members are committed to achieving sustainable resource management because the customary practices are parts of their identity; thus, ILSM benefits are as much about maintaining cultural practice as ensuring the availability of livelihoods and wellbeing derived from environmental services (Table 4 , indicator 5 b).

More recently, in 2010, the Zaira tribes independently adapted their customary resource management mechanisms to more formalized planning and implementation under an ILSM plan that integrates customary and scientific approaches, as per Aswani and Ruddle (2013). The plan: covers management rules for all linked ecosystems within the customary land and sea tenure boundaries of three cooperating tribes at the scale over which cross-system processes are occurring; has objectives that are focused on the maintenance of culture and tenure, food security, iconic species and education; and is discussed during annual meetings, with a 5year timeline for review (Tables $3 \& 4$, indicators $1 \mathrm{a}, 1 \mathrm{~b}, 1 \mathrm{f} \&$ $2 a-c)$. The evolution of Zaira's customary management system into more structured ILSM implementation has provided a platform of confidence, enabling the local management committee to enforce their authority on outsiders who are interested in resource extraction; recently, one high-profile case of a peaceful boarding of an international logging vessel that was illegally entering the management area was settled with significant financial compensation paid to Zaira community members (Table 4, indicators $7 \mathrm{a} \& 7 \mathrm{~b}$ ) (S. Albert, personal communication 2016). Meanwhile, internal conflicts and punishments for local offenders are dealt with through customary mechanisms (Table 4 , indicators $8 \mathrm{a} \& 8 \mathrm{~b})$.

\section{Constraints}

The governance and decision-making systems in Zaira are clear (Table 4, indicator 2d), but they do not allow for full participation of all segments of the population affected by management decisions (Table 4 , indicators $4 a \& 4 c$ ), which may ultimately lead to system vulnerabilities should future conditions change. Although the community-centric approach in Zaira is viewed by outsiders as bottom-up governance, internally the governance is relatively top-down and is not nested within broader government management systems (Table 4, indicator 10c). Lack of broad involvement is not currently an issue in Zaira, as resource users perceive that the chief represents their interests and values, but it may become a challenge in the future if respect for the customary governance system is eroded and top-down imposition of rules is perceived as less legitimate. Furthermore, there is no guarantee that the successor to the current chief will not be swayed by development interests (Table 4 , indicator $4 \mathrm{~d}$ ). A further constraint is that although formal land and sea tenure rights are recognized by Solomon Islands legislation (Hviding \& Baines 1994), the tenure and use rights boundaries 
Table 3 Summary information on integrated land-sea management project management objectives, resident populations within and/or affected by management area rules, sizes of management areas, nature of governance systems and entities driving the integrated land-sea management process. NGO = non-governmental organization.

\begin{tabular}{|c|c|c|c|c|c|c|}
\hline Project & Country & Management objective(s) & $\begin{array}{l}\text { Resident } \\
\text { population } \\
\text { size }\end{array}$ & $\begin{array}{l}\text { Management } \\
\text { area }\end{array}$ & Governance & $\begin{array}{l}\text { Entity } \\
\text { driving } \\
\text { management }\end{array}$ \\
\hline $\begin{array}{l}\text { Zaira Resource } \\
\text { Management } \\
\text { Area }\end{array}$ & $\begin{array}{r}\text { Solomon } \\
\text { Islands }\end{array}$ & $\begin{array}{l}\text { (1) Maintain traditional resource } \\
\text { management regime and local } \\
\text { leadership that recognizes cultural } \\
\text { values and protects historical } \\
\text { heritages; (2) sustainable use of } \\
\text { natural resources to meet the basic } \\
\text { present and future livelihood and } \\
\text { development needs of the } \\
\text { dependent local community; (3) } \\
\text { protect iconic species; (4) support } \\
\text { cultural and environmental } \\
\text { education of current and future } \\
\text { generations }\end{array}$ & 150 & $\begin{array}{l}\text { Terrestrial: } 25 \\
\mathrm{~km}^{2} \text {; marine: } \\
15 \mathrm{~km}^{2}\end{array}$ & Tribal chief & Community \\
\hline $\begin{array}{l}\text { Kubulau } \\
\text { District }\end{array}$ & Fiji & $\begin{array}{l}\text { (1) Maintain or restore marine } \\
\text { resources; (2) maintain ecosystem } \\
\text { connectivity and functionality; (3) } \\
\text { protect and provide good habitats } \\
\text { for endemic forest species; (4) } \\
\text { ensure sustainable land } \\
\text { management; (5) protect water } \\
\text { catchments; (6) provide economic } \\
\text { opportunities for the people of } \\
\text { Kubulau (WCS 2012) }\end{array}$ & $\sim 1000$ & $\begin{array}{l}\text { Terrestrial: } 98.5 \\
\mathrm{~km}^{2} \text {; marine: } \\
260.1 \mathrm{~km}^{2}\end{array}$ & Tribal chiefs & NGO \\
\hline $\begin{array}{l}\text { New Britain } \\
\text { East and West } \\
\text { Provinces }\end{array}$ & $\begin{array}{c}\text { Papua New } \\
\text { Guinea }\end{array}$ & $\begin{array}{l}\text { (1) Build capacity at the local, } \\
\text { provincial and national levels to } \\
\text { improve decision-making around } \\
\text { marine resource management in } \\
\text { the Bismarck Seascape; (2) develop } \\
\text { a comprehensive spatial } \\
\text { information dataset to support } \\
\text { decision-making, which is } \\
\text { accessible to a range of } \\
\text { stakeholders (through } \\
\text { comprehensive maps and a } \\
\text { supporting ridges-to-reefs plan); } \\
\text { (3) ridges-to-reefs planning and } \\
\text { management capable of informing } \\
\text { decisions across jurisdictions, as } \\
\text { well as being institutionalized } \\
\text { within provincial government, } \\
\text { district and tribal governance } \\
\text { structures }\end{array}$ & $\sim 450,000$ & $\begin{array}{l}\text { Terrestrial: } \\
37,000 \mathrm{~km}^{2} \text {; } \\
\text { marine: } \\
11,170 \mathrm{~km}^{2}\end{array}$ & Tribal chiefs & $\begin{array}{l}\text { Provincial } \\
\text { government }\end{array}$ \\
\hline Lāna'i, Hawai'i & USA & $\begin{array}{l}\text { Reducing threats to downstream } \\
\text { systems, restoring connectivity } \\
\text { across landscapes and across the } \\
\text { land-sea interface and maintaining } \\
\text { and restoring ecosystem services, } \\
\text { particularly: (1) plant cover, which } \\
\text { helps with aquifer recharge; (2) } \\
\text { hunting opportunities for local } \\
\text { community; and (3) productive, } \\
\text { healthy coastal environments for } \\
\text { recreational and provisioning } \\
\text { purposes }\end{array}$ & $\sim 3100$ & $\begin{array}{c}\text { Terrestrial: } \\
364 \mathrm{~km}^{2}\end{array}$ & $\begin{array}{l}\text { Private } \\
\text { landowner }\end{array}$ & $\begin{array}{l}\text { Private } \\
\quad \text { sector/NGO }\end{array}$ \\
\hline
\end{tabular}


Table 4 Evaluation of island integrated land-sea management projects: mean scores for Zaira (Z), Kubulau (K), New Britain (NB) and Lāna'i $(\mathrm{L})$ projects are shown. Cells shaded white show mean scores $\geq 1.5$, indicating strong project performance against the indicator. Cells shaded light grey show mean scores $>0.5$ and $<1.5$. Cells shaded dark grey show mean scores $\leq 0.5$, indicating poor project performance against the indicator.

\begin{tabular}{|c|c|c|c|}
\hline Indicator & $Z$ & $K$ & $N B$ \\
\hline 1a. Explicit timeframe of implementation stated (including overall timescale and review & 2 & 2 & 2 \\
\hline
\end{tabular}
frequency)

1b. Proportion of linked ecosystems incorporated in plan

1c. Presence of coordination body or mechanism to integrate sectors (e.g. public versus private; land versus sea mandates)

1d. Accounting for cumulative impact of multiple threats to the coastal zone

1e. Accounting for lag time for impacts to be realized and benefits from management to accrue across realms

1f. Objectives integrate ecological, social, economic and cultural issues and feedbacks that account for connectivity between land and sea realms

2a. Degree to which the spatial boundaries of the management zone match the boundaries of watersheds and linked coastal areas

2b. Management boundaries represent the scale of ecological processes and threats for priority features relevant to integrated land-sea management

2c. Resource users are aware of management boundaries

2d. Decision-makers and decision-making processes are clearly identified

3a. Appropriate strategies proposed and management actions are identified in order to minimize land-based threats to downstream systems relative to the number of issues

3b. Appropriate strategies are proposed and management actions are identified in order to restore connectivity processes relative to the number of issues

$3 \mathrm{c}$. Strength of social networks that connect people using land and sea resources

4a. Proportion of population who access and use land and sea resources in the management area are able to participate in management planning and implementation

4b. Proportion of different sectors and stakeholder groups across land and sea realms are participating relative to presence in area

4c. Opportunities for input from marginalized sectors of communities in affected areas

$4 \mathrm{~d}$. Consistency of mandate through changes in political leadership

5a. Management objectives reflect local concerns and issues related to cross-system threats and processes

5b. Local perception that the benefits of management outweigh costs

$5 \mathrm{c}$. Equity in distribution of management costs and benefits across land and sea resource users

6a. Level (formal or informal) of recognition of management authority

6b. Clearly defined and demarcated ownership of both land and sea and use rights of land and sea resources

7a. Frequency and effectiveness of monitoring, control and surveillance integrated across land and sea realms

7b. Proportion of offenses that are adequately punished across both land and sea

8a. Existence of forum or means to settle disputes

8 b. Perception that conflict resolution is handled fairly and in a culturally appropriate way

9a. Monitoring information relevant to the spatial scale of the impacts of human activities on linked ecosystems and responses of linked ecosystems to management interventions are communicated to decision-makers

9b. Decision-makers use relevant information to adapt management measures

9c. Adaptions to rules consider present and future uncertainty regarding cross-system threats and processes

10a. Management actions/monitoring is carried out by individuals across land and sea realms who report to a coordinating body

10b. Frequency and consistency of communication between lower to higher scales of nested systems (upward and downward communication)

10c. Consistency in goals and motivations between nested levels in achieving integrated land-sea management outcomes

\begin{tabular}{|c|c|c|c|}
\hline 2 & 2 & 1.5 & 1 \\
\hline 1.2 & 2 & 1.7 & 1.8 \\
\hline 2 & 2 & 0.8 & 0.6 \\
\hline 0 & 1 & 0 & 0.8 \\
\hline 2 & 2 & 2 & 2 \\
\hline 2 & 1 & 0 & 2 \\
\hline 1.8 & 1 & 1 & 2 \\
\hline 2 & 1.4 & 1 & 2 \\
\hline 2 & 1.4 & 1 & 1 \\
\hline 2 & 1.8 & 1.3 & 1.2 \\
\hline 2 & 1 & 1.5 & 1.2 \\
\hline 2 & 2 & 2 & 2 \\
\hline 1 & 1.2 & 0.8 & 0.2 \\
\hline 1.8 & 0.8 & 1.8 & 0.5 \\
\hline 0.4 & 1.2 & 1.3 & 0.2 \\
\hline 1.6 & 2 & 1.2 & 0.4 \\
\hline 2 & 2 & 1.5 & 0.8 \\
\hline 2 & 2 & 0.3 & 0 \\
\hline 2 & 2 & 0 & 0 \\
\hline 1.2 & 1.6 & 0.6 & 1.8 \\
\hline 0 & 2 & 0.3 & 2 \\
\hline 1.8 & 1 & 0.5 & 0.8 \\
\hline 1.2 & 0.6 & 0 & 0 \\
\hline 2 & 2 & 0.7 & 2 \\
\hline 1.8 & 1.8 & 0 & 0 \\
\hline 0.2 & 1.2 & 1.3 & 1.8 \\
\hline 0 & 0 & 0 & 2 \\
\hline 0.8 & 2 & 2 & 2 \\
\hline 0 & 2 & 0 & 1.8 \\
\hline 1 & 1 & 1 & 0.4 \\
\hline 0 & 1.8 & 0 & 0 \\
\hline
\end{tabular}


are not legally demarcated (Table 4 , indicator $6 \mathrm{~b}$ ), which can create conflict when outsiders who are interested in resource extraction or conservation are also interested in distributing benefits to the resource owners (Hviding 1996). Moreover, the government has authority to award timber rights to a third party without landowner consent (Hviding \& Bayliss Smith 2000), and has recently done so for the forests adjacent to Zaira (S. Albert, personal communication 2016), jeopardizing both land and linked sea ecosystems within the conservation area.

\section{Kubulau District, Fiji}

\section{Positive attributes}

The Kubulau project scored highly on some but not all indicators related to: adopting a long-term integrated approach to management; ensuring management systems reflect local values; ensuring management authority and rules are recognized; resolving conflicts; implementing evidencebased adaptive management; and nesting ILSM within existing governance systems operating across land and sea sectors (indicators associated with principles 1, 5, 6 and 810; Table 4). As in Zaira, local communities in Kubulau traditionally regulated local land and sea resource use through customary management; however, by the early 1990s, they realized that customary measures alone were insufficient to prevent commercial overexploitation of marine resources by outside users (Clarke \& Jupiter 2010b). The chiefs requested support from an international NGO specializing in natural resource management, who assisted the Kubulau leadership in 2009 to develop a district-level ILSM plan designed to regulate resource use and minimize the downstream impacts of land activities by facilitating dialogue across multiple stakeholders from the communities, government and private sector (Table 4, indicator 4a). The goals of the plan, which covers the entirety of the relatively intact Kubulau land and fisheries management area (Table 4, indicator $1 b$ ), reflect local values and are focused on ensuring ecosystem integrity for biodiversity conservation and maintaining important services (e.g. food and water provision) for livelihoods and wellbeing (Tables $3 \& 4$, indicators $1 f \& 5 a$ ).

The Kubulau ILSM plan outlines a governance structure that includes a coordination body (the Kubulau Resource Management Committee), made up of representatives from coastal and inland villages, which oversees management implementation (Table 4, indicator 1c). The Management Committee is nested within the traditional chiefly governance system, through which internal conflicts are resolved via customary mechanisms (Table 4 , indicators $8 \mathrm{a}, 8 \mathrm{~b}, 10 \mathrm{a} \&$ 10c). The plan was reviewed and adapted in 2012 based on monitoring data, local knowledge and community aspirations that consider future uncertainty (Table 4 , indicators $9 \mathrm{a} \&$ 9c) (Weeks \& Jupiter 2013). There is a general perception according to Kubulau community household survey data that management positively affects the state of resources (Table 4 , indicator $5 \mathrm{c}$ ), with a majority of respondents specifying some level of involvement in and a high degree of satisfaction with the management process (Table 4, indicator 5b) (Egli et al. 2010).

\section{Constraints}

The mismatch between the scale of threats and management implementation is an issue in Kubulau, where local actors are not capable of managing all of the threats to their ecosystems (Table 4, indicator 2b). In 1998, local communities attributed mass fish kills and coral die-offs downstream of the Yanawai River mouth to runoff from tailings released from an upstream gold mine (Jupiter et al. 2010). As the tailings ponds are located outside of the boundaries of Kubulau District near the headwaters of the Yanawai, the community has no influence on mining operations there, particularly as mining leases in Fiji may be granted over native land under the Mining Act without landowner consent (Clarke \& Jupiter 2010b). A second major constraint is that community ILSM plans are not legally recognized by the government (Clarke \& Jupiter 2010b), which particularly affects local ability to enforce notake freshwater and marine protected areas (Table 4, indicator 7b). The Fiji Fisheries Act permits all fishers to fish for subsistence anywhere in Fiji's fresh and coastal waters with certain permitted gear types, compromising the effectiveness of ILSM, as a large number of Fiji's fishes move between freshwater and marine realms during their lifecycles (Jenkins et al. 2010). Presently, the only legal mechanism available for completely prohibiting all subsistence and commercial fishing is for the Minister for Fisheries and Forests to gazette a marine protected area as a restricted area, but Kubulau communities, like others in Fiji, have been reluctant to use this instrument, as it would require ceding management control to the government (Clarke \& Jupiter 2010b).

\section{New Britain, PNG}

\section{Positive attributes}

The New Britain project scored highly on some but not all indicators related to: adopting a long-term integrated approach to management; ensuring broad sectoral participation in management planning across land and sea; ensuring management systems reflect local values; and adapting existing management (indicators associated with principles 1, 4, 5 and 9; Table 4). Through its commitments to the United Nations Convention on Biological Diversity's Programme of Work on Protected Areas and the Coral Triangle Initiative on Coral Reefs, Fisheries and Food Security, the PNG national government, with the support of NGOs and research partners, has developed national priorities for terrestrial and marine conservation. In recognition that these two prioritization processes were undertaken separately without considering the connectivity between land and sea, PNG's national Conservation and Environment Protection Authority, in partnership with the United Nations Development Programme (UNDP), funded an assessment of land-based threats to downstream coastal ecosystems from upstream land use and land cover change, using methods 
developed by Tulloch et al. (2016) that consider uncertainty in future development scenarios (Table 4, indicator 9c). The outputs from this connectivity assessment are being integrated into ILSM planning that is decentralized to New Britain Island (covering two provinces), which includes prioritization of locations for protected areas in order to specifically manage cross-system threats from land-based activities that increase sedimentation and negatively impact biodiversity. There are aspirations that at least some of these priority areas will become legally protected under new protected area legislation that is in development in PNG, although the protected area type and agencies responsible for their management are not yet clear.

An international NGO and an Australian research organization are facilitating the development of an ILSM plan for East New Britain as part of the Bismarck Sea Adaptive Governance project, which complements an ILSM plan that has already been completed for West New Britain with UNDP support (V. Tulloch, personal communication 2016). The contents of the two plans will be incorporated into 5-year sustainable development plans for provincial governments (Table 4, indicator 1a) with the aim of enabling community and government stakeholders to make informed and inclusive decisions in order to support sustainable resource management and economic development within an ILSM framework. All coastal ecosystems will be covered in the finalized plans (Table 4, indicator $1 \mathrm{~b}$ ) and a broad range of stakeholders have been included in consultations, including the National Fisheries Authority, the Mineral Resources Authority, provincial government staff, oil palm and deep-sea mining companies and representatives from local communities (Table 4, indicator 4b). Local values surrounding how connected terrestrial, freshwater and marine resources are used are being captured through participatory planning workshops with provincial-, district- and local-level government stakeholders in order to collate ecosystem goods and services' values and define management rules (Table 1 , indicator $5 \mathrm{a}$ ).

\section{Constraints}

Actual implementation of the individual ILSM plans and the integrated sustainable development plan for New Britain is likely to be challenged by resourcing, buy-in and enforcement issues. Current ILSM plan development is based on a 2-year funded project; while there is hope that additional funding will become available for another 5-10 years, the PNG national government has no immediate plans to mainstream the plans' implementation into government budgets and there is presently little buy-in from provincial governments (Table 4, indicators $4 d \& 10 a-c)$. Furthermore, because of customary tenure systems in PNG, implementation ultimately depends on land and reef owner participation in management. Yet the majority of indigenous land and reef owners have not been consulted regarding plan design (Table 4, indicator 4a) and may have contrary objectives. They may choose to $\log$ rather than restore lands (Table 4 , indicator $5 b$ ), thus potentially preventing implementation across the scales necessary for threat mitigation (Table 4, indicators $3 a \& 3 b$ ). Offenses for existing management are generally not punished (Table 4 , indicator $7 b$ ) and corruption is rife.

\section{Lāna'i, Hawai'i, USA}

\section{Positive attributes}

The Lāna'i project scored highly on indicators related to: adopting a long-term integrated approach to management; using clearly defined management boundaries at the appropriate scale; accounting for connectivity between ecological realms and social networks; ensuring that management authority and rules are recognized; and establishing the framework to implement evidence-based adaptive management (indicators associated with principles 1-3, 6 and 9; Table 4). Lanna'i, the sixth largest $\left(364 \mathrm{~km}^{2}\right)$ of the main Hawaiian Islands, suffers from extensive soil erosion due to proliferation of invasive feral ungulates (e.g. deer and sheep), with significant capacity to devegetate large parts of the island. Over 3000 people live on the island, although the majority of the land is privately owned by a single for-profit company, Pūlama Lāna'i, who run resorts on the island. The company is developing an ILSM plan covering the $98 \%$ of the island that it owns, while the remaining $2 \%$ is owned by local people, the State of Hawai' $i$ and The Nature Conservancy. Jurisdictionally, the management plan is likely to be easily implemented because: the local community and state recognize the management authority of the private land owner (Table 4, indicators 6a-c); land and sea ownership is clearly demarcated and recognized (Table 4 , indicators $2 \mathrm{a}-\mathrm{c}$ ); and the management and monitoring of the company land is well coordinated (Table 4, indicator 10a).

The goals of the plan are to reduce threats to downstream systems, restore connectivity across landscapes and across the land-sea interface and maintain and restore ecosystem services (Table 3). Proposed activities for watershed restoration, terrestrial and marine invasive species management and marine debris management will minimize sedimentation and maximize the potential for recovery of the nearshore reefs (Table 4, indicators $3 \mathrm{a} \& 3 \mathrm{~b}$ ). The ILSM plan will account for cumulative impacts to the coastal zone (Table 4, indicator 1e) by using outputs from quantitative models estimating soil erosion and dispersal to adjacent reefs, which will be coupled with evaluation of human fishing efforts and other marine uses (e.g. recreation) in order to assess reef impact and recovery potential. Scenarios will be developed based on various strategies for managing feral ungulates in order to prioritize areas for management and restoration. Plans are under development to install an integrated landsea monitoring system once the watersheds for restoration have been determined in order to monitor and evaluate management effectiveness (Table 1 , indicators $9 a-c$ ).

\section{Constraints}

Although a broad range of partners have been involved in discussions about management plan development, including 
the Hawai' $i$ Division of Aquatic Resources, the Hawai' $i$ Department of Fish and Wildlife and the US Fish and Wildlife Service, local residents of Lāna'i have not been consulted (Table 4, indicators $4 \mathrm{a}-\mathrm{c}$ ). Local residents have some values that are contradictory to those of the company and its management partners with respect to their preference to maintain populations of feral ungulates for hunting. They are thus not convinced that the management benefits will outweigh the costs to them in terms of lost hunting opportunities and view the company with some distrust (Table 4 , indicators $5 \mathrm{a}-\mathrm{c}$ ). The landowner is clear that the company will take local community concerns into account and will provide future opportunities for local engagement. However, there is little scope for local residents to question the company's management authority should their future interests diverge (Table 4 , indicator $4 \mathrm{~d}$ ).

\section{DISCUSSION}

Based on the constraints identified in the four island ILSM projects evaluated, we identify opportunities to improve the effectiveness of project planning and evaluation through increasing local participation in decision-making and mainstreaming ILSM into government, private sector or public-private partnership systems for durable and sustainable implementation. We additionally draw on the ILSM literature to identify best-practice examples from other regions that can serve as models for island ILSM projects, while recognizing that outcomes will additionally be influenced by the number of resources users and uses and governance capacity.

\section{Improving local participation in decision-making}

The common-pool and community-based resource management literature is rich in theory and examples of how local participation promotes more effective and accountable resource management policies and outcomes because local resource users have higher stakes in maintaining the sustainability of resources and have good local knowledge about local processes and feedback (e.g. Ostrom 1990; Brechin et al. 2002; Cox et al. 2010). Furthermore, various evaluations of island projects have emphasized the importance of community-driven decisions for regulating resource use (World Bank 1999; Pollnac \& Pomeroy 2005). For many Pacific Island systems, these local decision-making processes concerning access to and use of land and sea resources are embedded in customary governance structures operating across linked ridge-to-reef units (Ruddle et al. 1992; Hviding 1996). In places like Zaira and Kubulau, where customary governance is still strongly respected and largely supported by national legislation, participatory, communitybased management systems can be extraordinarily effective at restricting access and use according to fluctuations in resource availability, particularly as systems of customary management blend with more contemporary concepts of ILSM (Johannes
2002; Aswani \& Ruddle 2013). Thus, these customary systems should be supported and strengthened.

The ability to participate in management rule development during island ILSM planning will likely have a strong impact on the long-term sustainability of implementation. Giving all stakeholders the opportunity to voice opinions will improve buy-in (Kearney et al. 2007), although if these opinions are not valued, it can create dissatisfaction in the planning and implementation processes (e.g. Risvoll et al. 2014). In New Britain and Lāna'i, where outside actors are spearheading ILSM initiatives, the success of plan implementation will therefore hinge on engaging local landowners in order to ensure that they recognize both the process and the rules as legitimate.

Level of participation can potentially be increased by ensuring that local governance is nested within broader supporting agencies and structures (Ostrom 1990) and by working with influential actors to engage people across their social networks (Mills et al. 2014; Guerrero \& Wilson 2016), noting that participation will likely be more effective where there is cultural predilection towards social cooperation (Gurney et al. 2016). Expectations of all stakeholders must be clearly articulated from the outset or this could ultimately result in project failure if and when local actors do not feel that their objectives are being met and/or benefits are not distributed equitably (Christie 2005). Adequate time and effort must be given for participatory consultations in order to define management objectives, systems and rules, which may require donor education to ensure that project budgets and timelines allow for enough facilitated discussion to build a consensus. As an example of this, the participatory processes supporting the re-zoning of the Great Barrier Reef Marine Park, which is often upheld as a model of ILSM, took 6 years and included over 1000 meetings and the consideration of 31,000 written submissions to the management authority (Hughes et al. 2007).

\section{Mainstreaming ILSM for long-term implementation}

Governments have the capacity to create the legal enabling framework for ILSM and to harmonize laws across multiple sectors (e.g. forests, fisheries, environment and health) (Lane 2008) and multiple scales, from local rules to internationally agreed multilateral frameworks (e.g. Convention of Biological Diversity). While this does not happen frequently, it may improve policy implementation when local rules are recognized at higher levels (Christie 2005). Government-led processes, such as those from the New Britain project, also have the potential to design management that addresses the spatial scale of ecosystem processes and threats within the context of national policy and legislation. Decentralization and nesting of these broader government policies and plans should improve implementation when local actors have more ownership over decisions (Ostrom 1990). A prime example of this comes from island systems in the Philippines, where the Local Government Code of 1991 devolves most responsibility 
for coastal resource management, including the management of cross-system processes and threats, to local government units to manage from their inland boundaries to $15 \mathrm{~km}$ offshore (White et al. 2005).

Funding for many ILSM projects in developing countries has historically been donor-driven, resulting in cessation of implementation following project termination (Christie 2005; Pollnac \& Pomeroy 2005). Thus, mainstreaming ILSM into government budgets and agency mandates should enable longterm support, particularly for monitoring and enforcement, which local communities may be ill-equipped to carry out on their own (Christie \& White 1997; Christie 2005). This is exemplified in the Philippines where a Coastal and Marine Management Office was created within the Department of Environment and Natural Resources and coastal management issues, including ILSM, were resourced with funding from national budget allocations (Christie 2005; White et al. 2005). In order to achieve this, policy-makers controlling national accounts will need to be convinced that effective ILSM can achieve desirable high-level policy outcomes for food security, livelihoods, sustainable development and biodiversity conservation (Jupiter et al. 2014a). Secondly, in order for locally driven projects to be able to access mainstreamed government resources, local management objectives need to be directly linked to broader policies and plans. For example, gazettal of the Zaira Resource Management Area under the Solomon Islands Protected Areas Act 2010 would make it eligible in principle to receive support through legally mandated government financing mechanisms, although in practice Solomon Islands has yet to declare a single national protected area under the Act or to mobilize funds for their management.

Across highly dispersed island archipelagos, central government will not always have the resources to lead ILSM planning and implementation in more remote areas, and thus decentralization and coordination are essential (Lane 2008). Decentralization will only be effective, however, where local rights to organize and make rules regarding access and use of resources are recognized by higher authorities (Ostrom 1990). Where these rights do not presently exist, granting them to cooperatives of resource users who would be issued exclusive access for harvesting can be effective for incentivizing local actors to self-police and manage for long-term sustainability (e.g. Afflerbach et al. 2014). In areas like Kubulau (Fiji), where indigenous people's inherited resource use and access rights have been partially eroded as a consequence of colonial systems, devolving marine tenure rights from the State to traditional fishing owners is highly contentious (Vukikomoala et al. 2012). Thus, in the absence of the ability to give local people more direct control over ILSM implementation, projects should focus on improving resources for the enforcement of existing rules and building relationships between local wardens and magistrates in order to enhance opportunities for successful prosecutions. Improved sub-national and national policies can encourage these relationships and benefit cooperation among stakeholders that may not normally collaborate well with each other (White et al. 2006).

Where there are consistent roadblocks to accessing government funds for ILSM, opportunities can be investigated through private sector engagement, as in Lāna'i. In some cases, large-scale private landowners are motivated by the direct economic incentives of improving ecosystem service provision. For example, following presentations of modelled scenarios for land use planning incorporating ecosystem service values, Kamehameha Schools, a large landowner on the north shore of Oah'u (Hawai' $i$ ), is now working to implement a land use plan that prioritizes small-scale agriculture and forestry while also mitigating the negative impacts of runoff (Goldstein et al. 2012). Other landowners may be swayed to action through corporate social responsibility policies (MacDonald 2010). Small-scale private landholders can be incentivized towards better watershed management practices through payment for ecosystem services initiatives that collectively may act to reduce the pollution affecting downstream biodiversity (e.g. Brodie et al. 2012). In Kubulau, the management costs for implementing the district ILSM plan are offset by tourist user fees for entering the communitymanaged Namena Marine Reserve (Clarke \& Jupiter 2010b), although such schemes are unlikely to be practical or effective in very remote areas (Jupiter et al. 2014b). Other opportunities may exist for harnessing developers' fees paid into trust funds that could be leveraged towards strategic ILSM implementation, although the risks of funds being absorbed into consolidated revenue or being mismanaged are high, particularly in developing countries (Maron et al. 2016).

In summary, we have identified variability in how island ILSM projects are planned and implemented across geographic scales and with different actors driving the process. All projects would benefit from more inclusive participation of all stakeholder groups that are affected by management decisions across the land-sea divide. Local-scale projects could benefit from being nested within government policy frameworks in terms of long-term resourcing and external support. In general, outcomes will only be achieved where adequate government legal and institutional policies encourage rather than disincentivize ILSM. Application of our framework for periodic island ILSM project evaluation throughout the lifetimes of projects should ultimately lead to the better achievement of project goals regarding biodiversity conservation, sustainable livelihoods and human wellbeing, although the practicality of its use will ultimately depend on ensuring that ILSM projects are well-documented and that the information is readily obtainable.

\section{FUNDING}

Funding for workshops to develop this paper was provided by the Science for Nature and People Partnership (SNAPP) to the Ridges to Reef Fisheries Working Group. SNAPP is a collaboration of The Nature Conservancy, the Wildlife Conservation Society and the National Center for Ecological 
Analysis and Synthesis (NCEAS). Assessment of the Zaira and Kubulau case studies was additionally supported by National Science Foundation grants EF-1427453 and 1325874 , respectively.

\section{Supplementary Material}

For supplementary material accompanying this paper, visit https://doi.org/10.1017/S0376892917000091

\section{References}

Adams, V.M., Álvarez-Romero, J.G., Cawardine, J., Cattarino, L., Hermoso, V., Kennard, M.J., Linke, S., Pressey, R.L. \& Stoeckl, N. (2014) Planning across freshwater and terrestrial realms: cobenefits and tradeoffs between conservation actions. Conservation Letters 7: 425-440.

Afflerbach, J.C., Lester, S.E., Dougherty, D.T. \& Poon, S.E. (2014) A global survey of 'TURF-reserves', Territorial Use Rights for Fisheries coupled with marine reserves. Global Ecology and Conservation 2: 97-106.

Álvarez-Romero, J.G., Pressey, R.L., Ban, N.C., Vance-Borland, K., Willer, C., Klein, C.J. \& Gaines, S.D. (2011) Integrated landsea conservation planning: the missing links. Annual Reviem of Ecology, Evolution and Systematics 42: 381-409.

Álvarez-Romero, J.G., Adams, V.M., Pressey, R.L., Douglas, M., Dale, A., Auge, A., Ball, D., Childs, J., Digby, M., Dobbs, R., Gobius, N., Hinchley, D., Lancaster, I., Maughan, M. \& Perdrisat, I. (2015) Integrated cross-realm planning: a decisionmakers' perspective. Biological Conservation 191: 799-808.

Anderson, W.B. \& Polis, G.A. (1999) Nutrient fluxes from water to land: seabirds affect plant nutrient status on Gulf of California islands. Oecologia 118: 324-332.

Aston, J. (1999) Experiences of coastal management in the Pacific Islands. Ocean E Coastal Management 42: 483-501.

Aswani, S. \& Ruddle, K. (2013) Design of realistic hybrid marine resource management programs in Oceania. Pacific Science 67: 461-476.

Brechin, S.R., Wilshusen, P.R., Fortwangler, C.L. \& West, P.W. (2002) Beyond the square wheel: toward a more comprehensive understanding of biodiversity conservation as social and political process. Society and Natural Resources 15: 41-64.

Brodie, J.E., Kroon, F.J., Schaffelke, B., Wolanski, E.C., Lewis, S.E., Devlin, M.J., Bohnet, I.C., Bainbridge, Z.T., Waterhouse, J. \& Davis, A.M. (2012) Terrestrial pollutant runoff to the Great Barrier Reef: an update of issues, priorities and management responses. Marine Pollution Bulletin 65: 81-100.

Christie, P. (2005) Is integrated coastal management sustainable? Ocean E Coastal Management 48: 208-232.

Christie, P. \& White, A.T. (1997) Trends in the development of coastal area management in tropical countries: from central to community orientation. Coastal Management 25: 155-181.

Cicin-Sain, B. \& Knecht, R.W. (1998) Integrated Coastal and Ocean Management: Concepts and Practices. Washington, DC: Island Press.

Cicin-Sain, B. \& Belfiore, S. (2005) Linking marine protected areas to integrated coastal and ocean management: a review of theory and practice. Ocean E Coastal Management 48: 847-868.

Clarke, P. \& Jupiter, S.D. (2010a) Principles and Practice of Ecosystem Based Management: A Guide for Conservation Practitioners in the Tropical Western Pacific. Bronx, NY: Wildlife Conservation Society.

Clarke, P. \& Jupiter, S.D. (2010b) Law, custom and communitybased natural resource management in Kubulau District (Fiji). Environmental Conservation 37: 98-106.

Cox, M., Arnold, G. \& Villamayor Tomas, S. (2010) A review of design principles for community-based natural resource management. Ecology and Society 15: 38.

Egli, D.P., Tui, T., Jupiter, S.D. \& Caginitoba, A. (2010) Perception Surveys of Coastal Resource Use and Changes Following Establishment of a Marine Protected Area Netmork in Kubulau, Fiji. Technical Report no. 07/10. Suva, Fiji: Wildlife Conservation Society.

Ehler, C.N. (2003) Indicators to measure governance performance in integrated coastal management. Ocean $\mathbb{E}$ Coastal Management 46: 335-345.

Goldstein, J.H., Caldarone, G., Duarte, T.K., Ennaanay, D., Hannahs, N., Mendoza, G., Polasky, S., Wolny, S. \& Daily, G.C. (2012) Integrating ecosystem-service tradeoffs into landuse decisions. Proceedings of the National Academy of Sciences USA 109: 7565-7570.

Govan, H., Aalbersberg, W., Tawake, A. \& Parks, J.E. (2008) Locally-managed Marine Areas: A Guide to Supporting Community-based Adaptive Management. Suva, Fiji: LocallyManaged Marine Area (LMMA) Network.

Gresh, T., Lichatowich, J. \& Schoonmaker, P. (2000) An estimation of historic and current levels of salmon production in the Northwest Pacific ecosystem: evidence of a nutrient deficit in the freshwater systems of the Pacific northwest. Fisheries 25: 15-21.

Griffith, M.D. \& Ashe, J. (1993) Sustainable development of coastal and marine areas in small island developing states: a basis for integrated coastal management. Ocean E Coastal Management 21: 269-284.

Guerrero, A.M. \& Wilson, K.A. (2016) Using a socialecological framework to inform the implementation of conservation plans. Conservation Biology [www document]. URL http://dx.doi.org/10.1111/cobi.12832

Gurney, G.G., Cinner, J.E., Sartin, J., Pressey, R.L., Ban, N.C., Marshall, N.A. \& Prabuning, D. (2016) Participation in devolved commons management: multiscale socioeconomic factors related to individuals' participation in community-based management of marine protected areas in Indonesia. Environmental Science $\mathbb{E}$ Policy 61: 212-220.

Hazlitt, S.L., Martin, T.G., Sampson, L. \& Arcese, P. (2010) The effects of including marine ecological values in terrestrial reserve planning for a forest-nesting seabird. Biological Conservation 143: 1299-1303.

Hughes, T.P., Gunderson, L.H., Folke, C., Baird, A.H., Bellwood, D.R., Berkes, F., Crona, B., Helfgott, A., Leslie, H., Norberg, J., Nystrom, M., Olsson, P., Österblom, H., Scheffer, M., Schuttenberg, H., Steneck, R.S., Tengö, M., Troell, M., Walker, B., Wilson, J. \& Worm, B. (2007) Adaptive management of the Great Barrier Reef and the Grand Canyon World Heritage Areas. Ambio 36: 586-592.

Hviding, E, (1996) Guardians of Marovo Lagoon: Practice, Place, and Politics in Maritime Melanesia. Honolulu, HI: University of Hawaii Press.

Hviding, E. \& Baines, G.B.K. (1994) Community-based fisheries management, tradition and the challenges of development in Marovo, Solomon Islands. Development and Change 25: 1339. 
Hviding, E. \& Bayliss Smith, T. (2000) Islands of Rainforest: Agroforestry, Logging and Eco-tourism in Solomon Islands. London, UK: Ashgate.

Jenkins, A.P. \& Jupiter, S.D. (2011) Spatial and seasonal patterns in freshwater ichthyofaunal communities of a tropical high island in Fiji. Environmental Biology of Fishes 91: 261-274.

Jenkins, A.P. \& Jupiter, S.D. (2015) Natural disasters, health and wetlands: a Pacific small island developing state perspective. In: Wetlands and Human Health, eds. C.M. Finlayson, P. Horwitz \& P. Weinstein, pp. 169-192. Dordrecht, The Netherlands: Springer.

Jenkins, A.P., Jupiter, S.D., Qauqau, I. \& Atherton, J. (2010) The importance of ecosystem-based management for conserving migratory pathways on tropical high islands: a case study from Fiji. Aquatic Conservation: Marine and Freshmater Ecosystems 20 : 224-238.

Jenkins, A.P., Jupiter, S., Mueller, U., Jenney, A., Vosaki, G., Rosa, V., Naucukidi, A., Mulholland, K., Strugnell, R., Kama, M. \& Horwitz, P. (2016) Health at the sub-catchment scale: typhoid and its environmental determinants in Central Division, Fiji. EcoHealth 13: 633-651.

Johannes, R.E. (2002) The renaissance of community-based marine resource management in Oceania. Annual Reviem of Ecology and Systematics 33: 317-340.

Jupiter, S.D., Tui, T., Shah, S., Cakacaka, A., Moy, W., Naisilisili, W., Dulunaqio, S., Patrick, A., Qauqau, I., Yakub, N. \& Caginitoba, A. (2010) Integrating EBM Science to Assess Marine Protected Area Effectiveness: Clues from Coral Proxies of Land Disturbance, Ecological Assessments and Socioeconomic Surveys. Technical Report no. 02/10. Suva, Fiji: Wildlife Conservation Society.

Jupiter, S.D., Jenkins, A.P., Lee Long, W.J., Maxwell, S.L., Carruthers, T.J.B., Hodge, K.B., Govan, H., Tamelander, J. \& Watson, J.E.M. (2014a) Principles for integrated island management in the tropical Pacific. Pacific Conservation Biology 20: 193-205.

Jupiter, S.D., Cohen, P.J., Weeks, R., Tawake, A. \& Govan, H. (2014b) Locally-managed marine areas: multiple objectives and diverse strategies. Pacific Conservation Biology 20: 165-179.

Kearney, J., Berkes, F., Charles, A., Pinkerton, E. \& Wiber, M. (2007) The role of participatory governance of community-based management in integrated coastal and ocean management in Canada. Coastal Management 35: 79-104.

Lane, M.B. (2008) Strategic coastal governance issues in Fiji: the challenges of integration. Marine Policy 32: 856-866.

MacArthur, R.H. \& Wilson, E.O. (1967) The Theory of Island Biogeography. Princeton, NJ: Princeton University Press.

MacDonald, K.I. (2010) The devil is in the (bio)diversity: private sector 'engagement' and the restructuring of biodiversity conservation. Antipode 42: 513-550.

Maron, M., Ives, C.D., Kujala, H., Bull, J.W., Maseyk, F.J.F., Bekessy, S., Gordon, A., Watson, J.E.M., Lentini, P.E., Gibbons, P., Possingham, H.P., Hobbs, R.J., Keith, D.A., Wintle, B.A. \& Evans, M.C. (2016) Taming a wicked problem: resolving controversies in biodiversity offsetting. Bioscience 66: 489-498.

Mills, M., Álvarez-Romero, J. G., Vance-Borland, K., Cohen, P., Pressey, R. L., Guerrero, A. M. \& Ernstson, H. (2014) Linking regional planning and local action: towards using social network analysis in systematic conservation planning. Biological Conservation 169: 6-13.

Olsen, S.B., Tobey, J. \& Hale, L.Z. (1998) A learning-based approach to coastal management. Ambio 27: 611-619.

Ostrom, E. (1990) Governing the Commons: The Evolution of Institutions for Collective Action. New York, NY: Cambridge University Press.

Polis, G.A. \& Hurd, S.D. (1996) Linking marine and terrestrial food webs: allochthonous input from the ocean supports high secondary productivity on small islands and coastal land communities. The American Naturalist 147: 396-423.

Polis, G.A., Anderson, W.B. \& Holt, R.D. (1997) Toward an integration of landscape and food web ecology: the dynamics of spatially subsidized food webs. Annual Reviem of Ecology and Systematics 28: 289-316.

Pollnac, R.B. \& Pomeroy, R.S. (2005) Factors influencing the sustainability of integrated coastal management projects in the Philippines and Indonesia. Ocean E Coastal Management 48: 233251.

Ragosta, G., Evensen, C., Atwill, E.R., Walker, M., Ticktin, T., Asquith, A. \& Tate, K.W. (2011) Risk factors for elevated enterococcus concentrations in a rural tropical island watershed. Fournal of Environmental Management 92: 1910-1915.

Reuter, K.E., Juhn, D. \& Grantham, H.S. (2016) Integrated landsea management: recommendations for planning, implementation and management. Environmental Conservation 43: 181-198.

Risvoll, C., Fedreheim, G.E., Sandberg, A. \& BurnSilver, S. (2014) Does pastoralists' participation in the management of national parks in Northern Norway contribute to adaptive governance? Ecology and Society 19: 71.

Ruddle, K., Hviding, E. \& Johannes, R.E. (1992) Marine resource management in the context of customary tenure. Marine Resource Economics 7: 249-273.

Tulloch, V.J.D., Brown, C.J., Possingham, H.P., Jupiter, S.D., Maina, J. \& Klein, C. (2016) Improving conservation outcomes for coral reefs affected by future oil palm development in Papua New Guinea. Biological Conservation 203: 43-54.

Vukikomoala, K., Jupiter, S., Erasito, E. \& Chand, K. (2012) An Analysis of International Lam, National Legislation, Fudgements, and Institutions as they Interrelate with Territories and Areas Conserved by Indigenous Peoples and Local Communities. Report no. 19 Fiji. Bangalore and Delhi, India: Natural Justice and Kalpavriksh.

WCS (2012) Ecosystem-Based Management Plan: Kubulau District, Vanua Levu, Fiji. Suva: Wildlife Conservation Society [www document]. URL https://fiji.wcs.org/Portals/82/ Kubulau_EBM_Plan_2012_FINAL.pdf

Weeks, R. \& Jupiter, S.D. (2013) Adaptive comanagement of a marine protected area network in Fiji. Conservation Biology 27: 1234-1244.

White, A.T., Christie, P., D'Agnes, H., Lowry, K. \& Milne, N. (2005) Designing ICM projects for sustainability: lessons from the Philippines and Indonesia. Ocean E Coastal Management 48: 271-296.

White, A., Deguit, E., Jatulan, W. \& Eisma-Osorio, L. (2006) Integrated coastal management in Philippine local governance: evolution and benefits. Coastal Management 34: 287-302.

World Bank (1999) Voices from the Village: A Comparative Study of Coastal Resource Management in the Pacific Islands. Pacific Islands Discussion Paper Series No. 9. Washington, DC: World Bank. 